\title{
An Empirical Study into the Individual-Level Antecedents to Employee-Driven Innovation Chukwuemeka K. Echebiri
}

\author{
" Employees at all levels of the organization are perceived as innovation \\ capital or innovation assets."
}

Kesting and Ulhøi (2010)

\begin{abstract}
The purpose of this paper is to link individual-level factors (such as need for autonomy, selfleadership, and perceived job autonomy) to employee-driven innovation with self-leadership as an indirect link. The study is based on survey data of 315 employees in the banking sector, collected in two waves where the variables were separated in time. The hypothesized model was analysed using a structural equation model on Stata. First, it was found that the need for autonomy had an indirect association with employee-driven innovation through self-leadership. Second, the findings show that self-leadership had a positive relationship with employee-driven innovation. Finally, there was no support found for the moderating role of perceived job autonomy between self-leadership and employee-driven innovation. The findings in this paper are important because they identify individual-level antecedents of employee-driven innovation.
\end{abstract}

\section{Introduction}

Innovation refers to the series of steps organizations take to transform ideas into improved products, services, or processes, as a way of competing to differentiate themselves in the marketplace (Baregheh et al., 2009). Up to this point, innovation studies have been primarily concerned with innovations that mainly emanate from research and development (R\&D) departments. Recently, the roles of ordinary employees in innovation processes have become a focal point in innovation literature (Aasen et al., 2012; Deslee \& Dahan, 2018; Voxted, 2018). It has become imperative to regard all employees, irrespective of their role or capacity, as the "innovation capital" or asset of every organization (Kesting \& Ulhøi, 2010). As a result, organizations today expect more creativity, innovation, and involvement from employees in the rapidly changing business environment. This has led to a focus on the potential of ordinary employees as contributors to innovation (Price et al., 2012; Wihlman et al., 2014; Engen \& Magnusson, 2015).

R\&D-focused innovation in most companies has relied on the assumption that innovation requires special skills and should be restricted to a small group in the organization that possess these skills (Harmaakorpi \& Melkas, 2012). Today, this assumption is no longer tenable as previous studies have shown that all employees have the potential to contribute to innovation (Engen, 2016; Båckstrom \& Lindberg, 2018; Renkema, 2018). Employee-Driven Innovation (EDI) is a construct that describes an innovation emanating from employees who are not overtly required to do so (Høyrup, 2010; Kesting \& Ulhøi, 2010). Specifically, it refers to new ideas that are initiated and driven by ordinary employees well beyond their regular duties (Wihlman et al., 2014; Xin, 2016; Holmquist \& Johansson, 2019). On this basis, EDI is described as an extra role behaviour (Buhl, 2018; Renkema, 2018) that begins at the job task and worker level (Høyrup, 2012). What this suggests is that employees who get involved in EDI are merely acting on their own free will. They are innovators, so they innovate at their place of work. It is on this basis that Alasoini (2013) argued that the starting point for EDI is an employee's internal desire for creativity, learning, and development based on what De Spiegelaere and Gyes (2012) described as direct participation in the innovation process.

As stated above, EDI revolves around individuals who decide to accept and take on roles outside of their officially allotted duties. We thus require a better understanding of the factors that motivate individuals to participate in this kind of extra role behaviour. Specifically, this paper focuses on self-leadership, the 


\section{An Empirical Study into the Individual-Level Antecedents to Employee-Driven Innovation Chukwuemeka K. Echebiri}

need for autonomy, and perceived job autonomy in relation to EDI. Perceived job autonomy may not be considered among individual factors such as the need for autonomy and self-leadership. However, the perception of job autonomy by individual employees will depend on their own personal interpretation. This implies that different employees will recognise the same job and its level of job autonomy differently. Research shows that individual-level factors are essential in predicting organizational performance (Kim, 2005). In this paper, it is argued that the presence, perception, and interpretation by employees of these three mentioned factors serves as a form of motivation, whereby employees are encouraged to engage in EDI. Nevertheless, up to the present time individual-level antecedents to EDI have not been previously investigated. Therefore, this paper aims to examine the association between individual-level factors and EDI.

Self-leadership refers to the process through which an individual acquires and develops self-influence to achieve self-direction and self-motivation skills that are necessary to perform effectively in the workplace (Manz, 1992; Stewart et al., 2011; Amundsen \& Martinsen, 2015). The need for autonomy and perceived job autonomy looks at autonomy from various perspectives. Perceived job autonomy is related to the job characteristic model and comes across more as an external type of autonomy driven by workplace conditions (Hackman \& Oldham, 1975; Parker et al., 2017). Alternatively, the need for autonomy is considered as a basic need according to self-determination theory, suggesting more of an internal type of autonomy tied to the characteristics of individual employees (Ryan \& Deci, 2000; Deci \& Ryan, 2008b).

Accordingly, this paper makes the following contributions. First, this study empirically links individual-level factors to employee-driven innovation, thereby deepening and extending our understanding of the central role of individual factors when it comes to EDI. Second, through the positive association between a need for employee autonomy and self-leadership, this paper provides further empirical evidence of this relationship and extends it to EDI. In this regard, it further demonstrates a positive relationship between self-leadership and EDI. Additionally, self-leadership acted as an indirect link between the need for autonomy and EDI.

The rest of this article is structured as follows. The next section focuses on key constructs in this study, and builds the argument for setting up the research model and hypotheses. The research methodology section follows this. Next, the results are presented, and finally, the discussion and conclusions.

\section{Theory and Hypotheses}

\section{Need for autonomy and self-leadership}

Self-determination theory (SDT) is conceived as a macro-level theory of human motivation that addresses issues such as personality development, self-regulation, and universal psychological needs (Deci \& Ryan, 2008b). SDT centres around differentiation between autonomous motivation and controlled motivation, and suggests that these two types of motivations are different with respect to both their underlying regulatory processes and their accompanying experiences (Deci \& Ryan, 2008a). Furthermore, SDT suggests that behaviours are characterized depending on whether they are shaped by autonomous versus controlled motivation (Gagné \& Deci, 2005). Individuals who are autonomously motivated, experience volition in action, whereas those who are control motivated instead experience pressure to think and behave in a specific way (Deci \& Ryan, 2008b). In line with this, Yun, Neck, Cox, and Sims (2006) defined the need for autonomy as "a trait, predisposition, or an individual difference variable that refers to a personal need or eagerness to express one's initiative in doing one's job", while Norris (2008) defined it as "a person's desire to engage in activities of his or her choosing".

Self-leadership is about the influence one exerts over oneself to achieve self-motivation and self-direction, contingent on behaving in desirable ways (Manz, 1992; Neck \& Manz, 1996; Carmeli et al., 2006; Yun et al., 2006). It is rooted in several inter-related theories of selfinfluence, including self-regulation, self-control, intrinsic motivation, and self-management (Houghton \& Neck, 2002; Carmeli et al., 2006; Neck \& Houghton, 2006; Yun et al., 2006). This combination of theories is in contrast to conventional top-down leadership approaches, in which a single leader or a group of leaders aims to influence and control their work subordinates through certain behaviours and actions (Carmeli et al., 2006; Houghton et al., 2014). Instead, through self-leadership, individuals develop the requisite skills to enable their intrinsic motivational abilities to shine forth, instead of merely relying on their leaders for this (Williams, 1997). Self-leadership at work is thus an acknowledgement that even when employee behaviours are shaped by external forces such as 


\section{An Empirical Study into the Individual-Level Antecedents to Employee-Driven Innovation Chukwuemeka K. Echebiri}

hierarchical leadership in a company, they are ultimately controlled by forces internal to individual employees (Stewart et al., 2011).

Literature shows over time that three distinct but complementary cognitive and behavioural strategies of self-leadership have emerged. They are, namely: behaviour-focused strategies, natural reward strategies, and constructive thought pattern strategies (Carmeli et al., 2006; Houghton et al., 2012). Together these make up the construct of self-leadership (Houghton et al., 2012; Houghton \& Neck, 2002). Behaviour-focused strategies imply strategies that are aimed at increasing selfawareness, leading to greater management of behaviours (Manz, 1992), such as self-observation, goal setting, self-rewarding, self-correcting feedback and practice. (Carmeli et al., 2006; Houghton \& Neck, 2002). The natural reward strategies in contrast focus on positive experiences associated with a task and the process through which it is achieved. Finally, constructive thought pattern strategies involve visualizing successful performances, engaging in positive self-talk, and raising consciousness about beliefs and assumptions needed to change dysfunctional thinking (Houghton \& Neck, 2002).

Even though self-leadership and the need for autonomy are closely related, the need for autonomy at work is a latent trait, while self-leadership is a manifestation of a person's overall level of self-control (Yun et al., 2006). Self-leadership is influenced by the need for personal autonomy and helps motivate autonomous action (Norris, 2008). As Deci and Ryan (2008b) suggested, the need for autonomy is seen as an essential element of individualism, where taking personal responsibility is also crucial for self-leadership. Norris (2008) argued that employees who possess a personal need for autonomy appear to be more likely to take responsibility, participate in decision making, and practice selfleadership strategies.

Empirical studies have complemented theory to suggest a link between the need for autonomy and selfleadership. For example, Yun et al. (2006) found that an individual's perceived need for personal autonomy can subsequently determine the extent to which that individual engages in self-leadership. This is attributable to the fact that such employees are better able to make their own choices, act independently, and take action on certain decisions (Norris, 2008).

Based on the above arguments, the following hypothesis is proposed:

\section{H1: There is a positive relationship between the need for autonomy and self-leadership.}

\section{EDI and self-leadership}

EDI refers to the generation and implementation of new ideas by ordinary employees who are not formally assigned the task of innovation (Høyrup, 2012). Empirical evidence no longer upholds the view that only specific individuals or groups dominate creative thinking (Høyrup, 2012; Haapasaari et al., 2017; Bäckström \& Bengtsson, 2019 ). However, the notion of EDI focuses on the participation of ordinary employees in the company's innovation process. First, EDI indicates that innovative ideas can come from those outside of a selected group of employees with noninnovation specific roles. Instead, innovation could emerge from the insights of employees within the organization, such as customer-facing employees, shopfloor workers, and middle managers, among others (Kesting \& Ulhøi, 2010; Xin, 2016). Second, employees who engage in EDI perform extra-role behaviours because they engage in duties not formally assigned to them. Third, it shows that employees who always have been primarily involved in the execution of ideas can also generate, and/or select the most suitable ideas as well (Xin, 2016).

Innovations are typically described as complex procedures, consisting of a variety of different activities (Kesting et al., 2015). Previous studies have suggested that various stages of innovation belong to different domains of an organization. The ideation phases mostly occurs at the individual level, whereas the implementation phase occurs at the organizational level (Axtell et al., 2000). Accordingly, Echebiri, Engen, and Amundsen (Forthcoming, 2020) stated that EDI consists of three encompassing dimensions, namely: the emergence of and search for ideas, idea generation, and idea development and implementation. The emergence of and search for ideas along with idea generation, occur at the individual level. In contrast, idea development and implementation occur at the team or organizational level. The team's importance shows, as argued by Smith, Ulhøi, and Kesting (2012), that to successfully drive forward an idea implies that employees are involved throughout the process. Therefore, ordinary employees are enabled to be actively involved throughout the three phases of EDI.

Several studies have shown the positive effects of selfleadership on work outcomes (e.g. Neck, DiLiello, \& Houghton, 2006; Stewart et al., 2011), and emphasized its importance for the innovation process (e.g. Gomes, 


\section{An Empirical Study into the Individual-Level Antecedents to Employee-Driven Innovation Chukwuemeka K. Echebiri}

Curral, \& Caetano, 2015; Neck et al., 2006). Carmeli et al. (2006) found that self-leadership was positively associated with both self and supervisor ratings of innovative behaviours. Carmeli et al. (2006) suggested that people who possess good self-leadership qualities at the same time know how to achieve high levels of selfdirection and self-motivation. The outcome is that these individuals can learn to lead themselves and others. In their study, Neck et al. (2006) suggested that individuals with strong self-leadership are more likely to consider themselves as more creative and innovative, unlike those with weak self-leadership. According to Neck and Manz (1996), applying self-leadership strategies may result in several predictable outcomes such as creating a tendency towards creativity and innovation. Prussia, Anderson, and Manz (1998) described self-leadership as a vital foundation for an organization. Neck et al. (2006) argued that employees who possess high levels of selfleadership are more likely to achieve higher innovation and creative potential than employees who are low in self-leadership. Since behaviour-focused strategies increase self-awareness through such things as selfobservation and natural reward strategies, potential exists for promoting a positive experience concerning one's task. Consequently, self-leadership is crucial for employees in order to help initiate and drive company innovation. This likely means promoting extra-role behaviour by individuals at work, as well as positively encouraging EDI.

Based on the above, this study states the following hypothesis:

\section{H2: There is a positive relationship between self- leadership and EDI.}

\section{Need for autonomy and EDI}

Building on the previous argument regarding the need for personal autonomy along with EDI, this paper argues that employees with a higher need for autonomy are more inclined to engage in EDI. Thus, the following hypothesis is stated:

\section{H3: There is a positive relationship between the need for autonomy and EDI.}

\section{The mediating role of self-leadership}

The mediating role of self-leadership is not a new mechanism in the literature (Amundsen \& Martinsen, 2015). However, this paper proposes that the relationship between the need for autonomy and EDI are mediated by self-leadership. As previously stated, self-leadership is an actual manifestation of self-control
(Yun et al., 2006). Considering what actually happens in social reality regarding innovation, the mediation of selfleadership should be expected only to be partial.

\section{H4: Self-leadership partially mediates the relationship between need for autonomy and EDI.}

\section{The moderating role of perceived job autonomy}

Job autonomy is defined as "the degree to which the job provides substantial freedom, independence, and discretion to the employee in scheduling the work and in determining the procedures to be used in carrying it out" (Hackman \& Oldham, 1975). Based on the job characteristics model (JCM), job autonomy emerges as one of the five job characteristics that make a job more satisfying (Humphrey et al., 2007; Parker et al., 2017). Also, it is one of the four sub-dimensions of psychological empowerment (Spreitzer, 1995). Unlike the need for autonomy earlier discussed, perceived job autonomy is a more global concept, one that touches upon almost all aspects of a job (Kuvaas et al., 2016). At the core of job autonomy is the notion of perceived control concerning one's job (Ng \& Feldman, 2014). That is to the extent to which employees have the freedom to make decisions and carry out their tasks with less supervision (Morrison et al., 2005; Smith et al., 2012).

When a workplace environment offers higher autonomy, it implies that employees have significant freedom and discretion on how to plan and execute their job tasks (Morgeson \& Humphrey, 2006). Having a higher level of job autonomy means that employees assume greater responsibility for their own decisions and initiative, thus depending less on their supervisors (Hackman \& Oldham, 1975; Yun et al., 2006). As argued by Spector (1986), the extent that employees believe they can have a considerable impact on their work environment will influence how they react to it. On the contrary, lack of job control has been suggested to result in a sense of lower personal accomplishment (Kim \& Stoner, 2008). Axtell and Parker (2003) argued that giving employees more autonomy in their job encourages employees to go beyond their assigned roles and responsibilities.

In their meta-analysis of 415 empirical samples, $\mathrm{Ng}$ and Feldman (2014) observed that job autonomy was positively and significantly related to a wide variety of positive work outcomes that cut across sectional and longitudinal designs. Dhar's (2016) study shows that job autonomy, as a moderator, strengthened the relationship between leadership and innovative behaviour. In a recent study, Kurz, Husig, and Dowling (2018) found that job autonomy had a positive 


\section{An Empirical Study into the Individual-Level Antecedents to Employee-Driven Innovation Chukwuemeka K. Echebiri}

relationship with innovative behaviour. Previous studies show that perceived job autonomy is most crucial at the individual level, especially for the ideation stages. Employees who worked in a high task-autonomy work environment were found to have generated more creative ideas (Zhou, 1998). Smith et al. (2012) proposed that autonomous work structures are positively related to employee-driven idea generation. Consequently, when a job or "position" is designed in a manner that provides employees with high levels of autonomy, it will likely result in increased opportunities for EDI.

Based on this, the following hypothesis is proposed:

\section{H5: Perceived job autonomy will moderate the relationship between self-leadership and EDI, such that this relationship will be stronger with higher perceived job autonomy, and weaker with lower perceived job autonomy.}

\section{Method}

Data for this study was collected from employees working in the Norwegian banking sector, which is dominated by a few very large commercial banks, some regionally based and several small savings banks spread across the country (Cook, 2018). The bank was chosen because of its focus on innovation-driven by its employees. The survey was designed on an online platform called Nettskjema. Following research cooperation between the research team and the organization, the link to the survey was sent to an HR person in the organization, who then distributed the survey to the employees within the scope of the study.

To help minimize the effect of common method variance, which arises from self-report surveys (Chang et al., 2010), two ex-ante remedies were applied as recommended (Chang et al., 2010; Podsakoff et al., 2003). The variables were separated in time by collecting data in two waves. Self-leadership and need for autonomy were measured at time 1 (T1) whereas EDI and perceived job autonomy were measured at time 2 (T2). There was a time lag of 10 days between T1 and T2. Second, the items were counterbalanced in their order.

A total of 715 employees received the survey. At T1, 443 completed the survey, while 377 participated at T2. After linking respondents who completed both $\mathrm{T} 1$ and $\mathrm{T} 2$, there was a usable sample of 315 respondents representing a response rate of 44 percent. Table 1 shows the description of the respondents.

\section{Survey instruments}

The study used a survey-based approach and respondents were asked to rate the questions on a fivepoint Likert scale ranging from " 1 - strongly disagree to 5 - strongly agree."

EDI

EDI was measured based on a 13-item scale developed by (Echebiri, Engen, \& Amundsen, in press). The scale consists of the following three sub-dimensions: Emergence and search for ideas (four items), idea generation (three items), and idea development and implementation (six items). Sample items include emergence and search for ideas ("I recognize when there is an opportunity for improvement with a practice"), idea generation ("I come up with creative ideas that might improve the daily work"), and idea development and implementation ("When a developed idea is put into practice, it becomes part of the routine"). The reliability for EDI was .70.

\section{Perceived job autonomy}

Three items were adopted from the work design questionnaire (Morgeson \& Humphrey, 2006). The items were: "The job gives me good opportunities to take personal initiatives or consider how to do the work", "The job allows me to make my own decisions", and "I have great freedom of decision in my work". Cronbach's alpha was .77

\section{Self-leadership}

The items were adopted from the abbreviated selfleadership questionnaire (Houghton et al., 2012). The scale comprises of three dimensions with each dimension measured with three items. The dimensions were: Behaviour Awareness \& Volition (I establish specific goals for my own performance), Task Motivation (I visualize myself successfully performing a task before I do it), and Constructive cognition (Sometimes I talk to myself, out loud or in my head, to work through a difficult situation). The factor reliability coefficient of self-leadership was .73.

\section{Need for autonomy}

Three items were adopted from Yun (2006). The items include: "I would find solutions to my problems at work without consulting my supervisor", "I would make decisions on my own initiative without involving my supervisor", and "I would collaborate with other employees at my level to accomplish tasks without involving my supervisor". Cronbach's alpha was .80. 


\section{An Empirical Study into the Individual-Level Antecedents to Employee-Driven Innovation Chukwuemeka K. Echebiri}

Table 1. Respondents profile $(\mathrm{N}=315)$

$\begin{array}{lll}\text { Gender } & \text { Frequency } & \text { Percentage } \\ \text { Female } & & \\ \text { Male } & 159 & 50.5 \\ & 156 & 49.5 \\ \text { Contact with customers/users } & & \\ \text { Yes } & 250 & 79.4 \\ \text { No } & 65 & 20.6 \\ & & \\ \text { Education } & 36 & 11.4 \\ \text { Secondary } & 68 & 21.6 \\ \text { One year post-secondary } & 129 & 41.0 \\ \text { Bachelors degree } & 82 & 26.0 \\ \text { Master degree or higher } & & \end{array}$

\section{Data analysis}

Structural equation modelling (SEM) was performed with Stata version 15.1 using a maximum likelihood estimation. The analyses were carried out in four major steps. First, the measurement model was validated using a confirmatory factor analysis (CFA). Next, the analysis proceeded with the structural model, as recommended in previous studies (Acock, 2013; Mehmet \& Jakobsen, 2017). SEM was performed based on the measurement model to estimate the fit of the hypothesized model to the data. Next, the analysis of the indirect effect was performed on Stata. Finally, the moderation analysis was performed using SPSS version 25.

\section{Results}

The means, standard deviations and latent bivariate correlations for all the variables included in the present study are reported in Table 2.

\section{Measurement model}

The measurement model consisted of one first-order construct (the need for autonomy), and two-second order constructs that had multiple indicators (selfleadership and EDI). Perceived job autonomy was not included because the moderation was performed separately, as previously stated. The model indicated a good fit $\left[\chi^{2}(243)=395.29\right.$; CFI $=.93$; TLI $=.92$; RMSEA $=$ .05 ; SRMR $=.06]$. The average variance extracted that was used to gauge construct validity did not reveal any problems. With a satisfactory measurement model, the next step was to test the structural model.

\section{Hypotheses testing}

Since H1, H2, and H3 were based on the bivariate relationships, the hypotheses were tested based on latent variable correlations obtained in Table 1. H1 suggested a positive association between the need for autonomy and self-leadership. This hypothesis was

Table 2. Descriptive statistics and latent variables correlations

$$
\text { Mean(SD) } 1
$$

ES $\quad 4.7(.47)$

IG $\quad 3.8(.74) \quad .48^{* * *}$

IDM $\quad 3.7(.64) \quad .43^{* * *}$

EDI $\quad 4.1(.46)$.NA

$\begin{array}{lll}\text { NFA } & 3.7(.85) & .07\end{array}$

PJA 4.1(.77) $41 .{ }^{* * *}$

SL $\quad 3.9(.50) \quad .60^{* * *}$
2

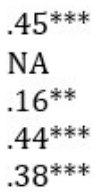

3

$\mathrm{NA}$

$-.04$

$.52^{* * *}$

$.48^{* * *}$
4

.12

$70 .^{* * *} \quad-.03$

$.71^{* * *} \quad .16^{*}$
19

Note: ES = Emergence and search for ideas, IG = idea generation, IDM = idea development and implementation, EDI = employeedriven innovation, NFA = need for autonomy, PJA = perceived job autonomy and SL = Self-leadership, NA = Not applicable

$$
{ }^{*} p<.05,{ }^{* *} p<.01,{ }^{* * *} p<.001
$$




\section{An Empirical Study into the Individual-Level Antecedents to Employee-Driven Innovation Chukwuemeka K. Echebiri}

Table 3. Moderation effects of perceived job autonomy

\begin{tabular}{|c|l|c|c|c|c|}
\hline Model & & $\begin{array}{c}\text { Std. coefficients } \\
\text { Beta }\end{array}$ & Std. Error & $\mathrm{t}$ & Sig \\
\hline 1 & Constant & & .02 & 183.88 & .000 \\
\hline & SL & .26 & .04 & 5.58 & .000 \\
\hline & PJA & .47 & .03 & 9.84 & .000 \\
\hline & SL x PJA & -.02 & .06 & -.48 & .632 \\
\hline
\end{tabular}

Note: SL = Self-leadership, PJA = Perceived job autonomy. Dependent variable $=$ EDI.

supported $(\mathrm{r}=.16, \mathrm{p}<.05) . \mathrm{H} 2$ postulated a positive relationship between self-leadership and EDI. This hypothesis was also supported by the data $(\mathrm{r}=.71, \mathrm{p}<$ .001). H3 suggested a positive relationship between the need for autonomy and EDI, but was not supported $(\mathrm{r}=$ $.12, \mathrm{p}<. \mathrm{ns}) . \mathrm{H} 4$ proposed that the relationship between the need for autonomy and EDI is mediated by selfleadership. This mediation hypothesis was not supported because of the non-significant relationship between need for autonomy and EDI. However, with significant relationships between need for autonomy and self-leadership (H1), as well as between selfleadership and EDI (H2), this satisfied the conditions for an indirect relationship in the data between need for autonomy and EDI (Mathieu et al., 2008).

\section{Test of the indirect effect}

A test of the indirect effect was conducted based on a structural model, which fit the data well. The test was performed using Monte Carlo replications in Stata. The number of Monte Carlo replications was set to 5,000.
The average indirect effect of the need for autonomy in EDI through self-leadership was estimated to .10, $\mathrm{SE}=$ $.05, \mathrm{p}<.05$.

\section{Moderation analyses}

H5 suggested that perceived job autonomy would moderate the relationship between self-leadership and EDI, such that this relationship would be stronger when there is higher perceived job autonomy, and weaker with lower perceived job autonomy. To reduce the potential for multicollinearity between lower-order and higherorder terms, the variables were mean-centred. As shown in Table 3, the data did not support the hypothesis.

The results of hypotheses testing are summarized in Figure 1.

\section{Supplementary analysis}

A supplementary analysis was performed regarding the relationship between self-leadership and the various sub-dimensions (stages) of EDI. To remind, these are:

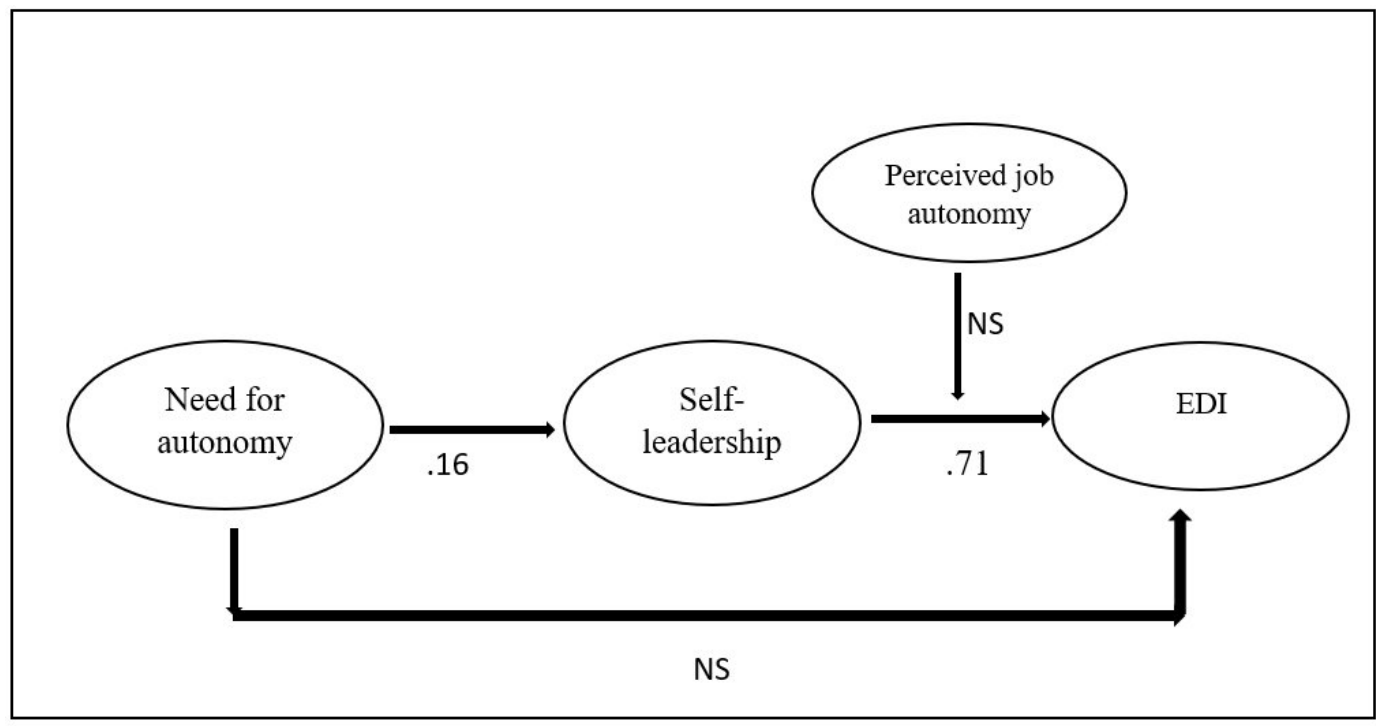

NS = Not supported

Figure 1. Complete hypothesized model included results of the hypotheses testing 


\section{An Empirical Study into the Individual-Level Antecedents to Employee-Driven Innovation Chukwuemeka K. Echebiri}

the emergence and search for ideas, idea generation, and idea development and implementation. This structural model gave a mixture of acceptable and nonacceptable fit indices. The modification indices were used to check for areas of improvement, and indicated allowing two pairs of error terms to correlate that belonged to the same construct. The model improved and indicated that the supplementary model was satisfactory $\left[\chi^{2}(181)=314.01, \mathrm{p}<.001 ; \mathrm{CFI}=.94\right.$; TLI $=$ .92 ; RMSEA $=.05$; SRMR $=.07]$. It was found that selfleadership had a positive relationship with emergence and search for ideas $(\beta=.71, p<.001)$, idea generation $(\beta$ $=.54, \mathrm{p}<.001)$, and idea development and implementation $(\beta=.59, \mathrm{p}<.001)$.

\section{Discussion}

The main aim of this paper was to investigate how individual-level variables (need for autonomy, perceived job autonomy, and self-leadership) associate with EDI. First, it was found that the need for autonomy had a positive relationship with self-leadership, and an indirect association with EDI through self-leadership. Second, it was established that self-leadership has a positive association with EDI. Contrary to the hypotheses presented, there was no support for a direct positive association between the need for autonomy and EDI, and for the moderating role of perceived job autonomy between self-leadership and EDI. Additionally, the supplementary model indicated that self-leadership has a positive relationship on all stages of EDI.

The findings in this paper give additional support to some earlier findings on relationships in management research. The result of a positive correlation between the need for autonomy and self-leadership agrees with previous results (Yun et al., 2006). This implies that employees who have more need for autonomy are likely to be more motivated to lead themselves because such people can express themselves at work, display positive behaviours (Yun et al., 2006; Ng \& Feldman, 2014), and thereby increase the likelihood of becoming more innovative and vice versa.

The positive relationship between self-leadership and EDI is also in line with previous studies where selfleadership was found to predict innovation (Neck et al., 2006). However, this is the first empirical paper to demonstrate a positive relationship between selfleadership and EDI, as well as an indirect association between the need for autonomy and EDI. Similarly, the positive association between self-leadership and the three phases of EDI (emergence and search for ideas, idea generation, and idea development and implementation) is also a crucial finding, as it links selfleadership to both the individual and organizational stages of EDI. Innovation literature suggests that different stages of innovation belong to their respective domains in the organization. For example, individual behaviour such as idea generation belongs to the individual level. In contrast, implementation phases belong to the organizational, group, or team level (Axtell et al., 2000).

These results, clearly underscore the central role of individuals in initiating and driving the innovation process. EDI is about ordinary employees participating in the entire innovation process (De Spiegelaere \& Gyes, 2012; Smith et al., 2012). This is because their involvement is beyond mere ideation (Båckstrom \& Lindberg, 2018). Furthermore, it also brings to light a new understanding that the development and implementation of an innovative idea within the context of EDI belongs to both the individual and organizational domains. This is theoretically understandable because employees on their own cannot implement innovation, though they are involved in the process.

Therefore, it is safe to say that the supplementary findings in this paper not only re-affirm our understanding of innovation, but also extend this understanding. As earlier stated in this section, the moderating role of perceived job autonomy was not supported by the data. Instead, self-leadership had the same impact on EDI regardless of whether perceived job autonomy is low or high. Nevertheless, despite the design of this paper, it still suffers from the weaknesses associated with a cross-sectional survey that has no real causality.

\section{Theoretical and practical implications}

Based on these findings, the following implications can be deduced. From a theoretical point of view, the various implementation phases of an innovation process ideally belong to the organizational domain (Axtell et al., 2000). This paper brings a new perspective to that long-held view. From the perspective of self-leadership studies, this finding is not entirely surprising, as self-leadership has been extended to the group level analysis (Stewart et al., 2011). The finding suggests that EDI, as both a process and an outcome, belongs to individual and organizational domains. Idea development and implementation require a level of self-leadership on the part of employees that runs beyond resources and other factors associated with the organizational domain. This 


\section{An Empirical Study into the Individual-Level Antecedents to Employee-Driven Innovation Chukwuemeka K. Echebiri}

is the most important theoretical contribution of the paper.

From a practical perspective, external factors such as leadership are crucial for innovation (Hughes, Lee, Tian, Newman, \& Legood, 2018). This includes EDI, while selfleadership skills are also important. The management and leadership of an organization should be aware that individual-level factors can engender EDI. There is no guarantee that management or good leadership alone can adequately motivate employees to become innovative if they cannot lead themselves. The implication here is that organizations should strive to complement external influences with internal incentives such as rewarding employees for valuable examples of self-leadership. Employees who can lead themselves are in a better position to identify a problem or perceive an opportunity at work, in a way that allows them to contribute more actively to the development and implementation of their ideas.

In conclusion, the findings in this paper suggest that the management, line managers, supervisors, and human resources department should be aware that employees with a high need for autonomy are in a better position to self-lead themselves. This is in line with Houghton et al. (2014) argument that internal forces ultimately shape behaviours. Organizations should therefore strive to create an opportunity for employees with a high need for autonomy to develop their skills to influence themselves and others, because through self-leadership, they can lead themselves to become more innovative in the company.

\section{Acknowledgement}

The author wishes to thank Associate Professor Stein Amundsen for his comments and suggestions in the course of developing this paper.

\section{References}

Aasen, T.M.B., Amundsen, O., Gressgård, L.J., \& Hansen, K. 2012. In search of best practices for employeedriven innovation: experiences from Norwegian work life. In S. Høyrup, M. Bonnafous-Boucher, C. Hasse, M. Lotz, \& K. Møller (Eds.), Employee-Driven Innovation: A New Approach. Basingstoke: Palgrave Macmillan: 57-74.

Acock, A.C. 2013. Discovering Structural Equation Modeling Using State. Stata Press.

Alasoini, T. 2013. Promoting employee-driven innovation: putting broad-based innovation policy into practice. Paper presented at the International Helix Conference, Linkoping, Sweden. Conference Accessed:

https://nrw.dgb.de/archiv/++co++b6cc7320-de4911e2-8e93-00188b4dc422

Amundsen, S., \& Martinsen, Ø.L. 2015. Linking Empowering Leadership to Job Satisfaction, Work Effort, and Creativity: The Role of Self-Leadership and Psychological Empowerment. Journal of Leadership \& Organizational Studies, 22(3): 304-323. doi:10.1177/1548051814565819

Axtell, C.M., Holman, D.J., Unsworth, K.L., Wall, T.D., Waterson, P.E., \& Harrington, E. 2000. Shopfloor innovation: Facilitating the suggestion and implementation of ideas. Journal of Occupational and Organizational Psychology, 73(3): 265-285. doi:10.1348/096317900167029

Axtell, C.M., \& Parker, S.K. 2003. Promoting Role Breadth Self-Efficacy Through Involvement, Work Redesign and Training. Human Relations, 56(1): 113-131. doi:10.1177/0018726703056001452

Baregheh, A., Rowley, J., \& Sambrook, S. 2009. Towards a multidisciplinary definition of innovation. Management Decision, 47(8): 1323-1339. doi:10.1108/00251740910984578

Buhl, A. 2018. Do it yourself - a lean startup toolbox for employee-driven green product innovation. Int. J. Entrepreneurship and Innovation Management, 22(4/5): 526 - 544

Bäckström, I., \& Lindberg, M. 2019. Varying involvement in digitally enhanced employee-driven innovation. European Journal of Innovation Management, 22(3): 524-540.

doi:10.1108/EJIM-01-2018-0008

Båckstrom, I., \& Lindberg, M. 2018. Behavioural Implications of Employee-Driven Innovation - A Critical Discourse Analysis. International Journal of Innovation Management, 22(07): 1850058. doi:10.1142/s1363919618500585

Carmeli, A., Meitar, R., \& Weisberg, J. 2006. Selfleadership skills and innovative behavior at work. International Journal of Manpower, 27(1): 75-90. doi:10.1108/01437720610652853

Chang, S.-J., Witteloostuijn, A.v., \& Lorraine, E. 2010. From the Editors: Common Method Variance in International Business Research. Journal of International Business Studies, 41(2).

Cook, H.M. 2018. Norway's banking sector: Facts \& Figures. Retrieved from:

https://www.ebf.eu/norway/

De Spiegelaere, S., \& Gyes, V.G. 2012. Employee-Driven Innovation and Industrial Relations. In S. Høyrup, M. Bonnafous-Boucher, C. Hasse, M. Lotz, \& K. Møller (Eds.), Employee-Driven Innovation: A New Approach, Palgrave Macmillian: 230-245.

Deci, E.L., \& Ryan, R.M. 2008a. Facilitating optimal motivation and psychological well-being across life's domains: Correction to Deci and Ryan (2008). Canadian Psychology/Psychologie canadienne, 49(3): 


\section{An Empirical Study into the Individual-Level Antecedents to Employee-Driven Innovation Chukwuemeka K. Echebiri}

262-262.

doi:10.1037/0708-5591.49.3.262

Deci, E.L., \& Ryan, R.M. 2008b. Self-determination theory: A macrotheory of human motivation, development, and health. Canadian Psychology/Psychologie canadienne, 49(3): 182-185. doi: $10.1037 / \mathrm{a} 0012801$

Deslee, C., \& Dahan, A. (2018). Employee-driven innovation into practice: managing the tension between organisation and innovation. International Journal of Entrepreneurship and Innovation Management, 22(4/5): 323-337.

Echebiri, C., Engen, M., \& Amundsen, S. (In press). Employee-Driven Innovation: Conceptualisation, Scale Development and Preliminary Validation. International Journal of Entrepreneurship and Innovation Management.

Engen, M. 2016. Frontline employees as participants in service innovation processes: innovation by weaving. Høgskolen i Lillehammer, Lillehammer, (6).

Engen, M., \& Magnusson, P. 2015. Exploring the role of front-line employees as innovators. The Service Industries Journal, 35(6): 303-324.

doi:10.1080/02642069.2015.1003370

Gagné, M., \& Deci, E.L. 2005. Self-determination theory and work motivation. Journal of Organizational Behavior, 26: 331-362. doi:10.1002/job.322

Gomes, C., Curral, L., \& Caetano, A. 2015. The Mediating Effect of Work Engagement on the relationship between Self-Leadership and Individual Innovation. International Journal of Innovation Management, 19(01): 1550009.

doi:10.1142/s1363919615500097

Hackman, J.R., \& Oldham, G.R. 1975. Development of the Job Diagnostic Survey. Journal of Applied Psychology, 60(2): 159-170.

doi:10.1037/h0076546

Harmaakorpi, V., \& Melkas, H. 2012. Epilogue: Two Modes of Practice-Based Innovation. In H. Melkas \& V. Harmaakorpi (Eds.), Practice-Based Innovation: Insights, Applications and Policy Implications. Berlin, Heidelberg: Springer.

Holmquist, M., \& Johansson, A. 2019. Employee-driven innovation: An intervention using action research. Technology Innovation Management Review, 9(5): 4453. doi:10.22215/timreview/1240

Houghton, J.D., Carnes, A., \& Ellison, C.N. 2014. A CrossCultural Examination of Self-Leadership. In MISSING. Flint, Michigan: 414-430.

Houghton, J.D., Diliello, T.C., \& Dawley, D. 2012. The Abbreviated Self-Leadership Questionnaire (ASLD): A More Concise Measure of Self-Leadership. International Journal of Leadership Studies, 7(2): 218231.

Houghton, J.D., \& Neck, C. 2002. The revised selfleadership questionnaire: Testing a hierarchical factor structure for self-leadership. Journal of Managerial
Psychology, 17(8): 672-691. doi:10.1108/02683940210450484

Hughes, D.J., Lee, A., Tian, A.W., Newman, A., \& Legood, A. 2018. Leadership, creativity, and innovation: A critical review and practical recommendations. The Leadership Quarterly, 29(5): 549-569. doi:10.1016/j.leaqua.2018.03.001

Humphrey, S.E., Nahrgang, J.D., \& Morgeson, F.P. 2007. Integrating motivational, social, and contextual work design features: A meta-analytic summary and theoretical extension of the work design literature. In MISSING. Washington, D.C.: 1332-1356.

Høyrup, S. (2010). Employee-driven innovation and workplace learning: basic concepts, approaches and themes. Transfer: European Review of Labour and Research, 16(2): 143-154.

doi:10.1177/1024258910364102

Høyrup, S. 2012. Employee-Driven Innovation: A New Phenomenon, Concept and Mode of Innovation. In S. Høyrup, M. Bonnafous-Boucher, C. Hasse, M. Lotz, \& K. Møller (Eds.), Employee-Diven Innovation: A new Approach. New York: Palgrave Macmillian: 3-34.

Kesting, P., \& Ulhøi, J. 2010. Employee-driven innovation: extending the license to foster innovation. Management Decision, 48(1): 65-84. doi:10.1108/00251741011014463

Kim, H., \& Stoner, M. 2008. Burnout and Turnover Intention Among Social Workers: Effects of Role Stress, Job Autonomy and Social Support. Administration in Social Work, 32(3): 5-25. doi:10.1080/03643100801922357

Kim, S. 2005. Individual-Level Factors and Organizational Performance in Government Organizations. Journal of Public Administration Research and Theory, J-PART, 15(2): 245-261.

Kurz, V., Husig, S., \& Dowling, M. 2018. What drives different employee types of innovative behaviour? Development and test of an integrative model of employee driven innovation in German firms. International Journal of Entrepreneurship and Innovation Management, 22(4/5): 397-426.

Kuvaas, B., Buch, R., \& Dysvik, A. 2016. Performance Management: Perceiving Goals as Invariable and Implications for Perceived Job Autonomy and Work Performance. Human Resource Management, 55(3): 401-412.

doi:10.1002/hrm.21680

Manz, C. 1992. Self-Leadership . . . The Heart of Empower. The Journal for Quality and Participation, 15(4): 1-10.

Mehmet, M., \& Jakobsen, T.G. 2017. Applied Statistics Using Stata: A Guide for the Social Sciences. London: SAGE.

Morgeson, F.P., \& Humphrey, S.E. 2006. The Work Design Questionnaire (WDQ): Developing and Validating a Comprehensive Measure for Assessing Job Design and the Nature of Work. Journal of Applied Psychology, 91(6): 1321-1339. doi:10.1037/0021-9010.91.6.1321 


\section{An Empirical Study into the Individual-Level Antecedents to Employee-Driven Innovation Chukwuemeka K. Echebiri}

Morrison, D., Cordery, J., Girardi, A., \& Payne, R. 2005. Job design, opportunities for skill utilization, and intrinsic job satisfaction. European Journal of Work and Organizational Psychology, 14(1): 59-79. doi:10.1080/13594320444000272

Neck, C., DiLiello, T.C., \& Houghton, J.D. 2006. Maximizing organizational leadership capacity for the future. In: MISSING, Bradford, England: 319-337.

Neck, C., \& Houghton, J.D. 2006. Two decades of selfleadership theory and research: past developments, present trends, and future possibilities. Journal of Managerial Psychology, 21(4): 270-295. doi:10.1108/02683940610663097

Neck, C., \& Manz, C. 1996. Thought self-leadership: the impact of mental strategies training on employee cognition, behavior, and affect. Journal of Organizational Behavior, 17: 445-467.

Ng, T.W.H., \& Feldman, D.C. 2014. The Moderating Effects of Age in the Relationships of Job Autonomy to Work Outcomes. Work, Aging and Retirement, 1(1): 6478. doi:10.1093/workar/wau003

Norris, S.E. 2008. An Examination of Self-Leadership. Emerging Leadership Journeys, 1(2): 43-61.

Parker, S.K., Morgeson, F.P., \& Johns, G. 2017. One hundred years of work design research: Looking back and looking forward. Journal of Applied Psychology, 102(3): 403-420. doi:10.1037/apl0000106

Podsakoff, P.M., MacKenzie, S.B., Lee, J.Y., \& Podsakoff, N.P. 2003. Common method biases in behavioral research: a critical review of the literature and recommended remedies. Journal of Applied Psychology, 88(5): 879-903.

doi:10.1037/0021-9010.88.5.879

Price, O.M., Boud, D., \& Scheeres, H. 2012. Creating Work: Employee-Driven Innovation through Workplace Reconstruction. In S. Høyrup (Ed.), Employee-Driven Innovation: A New Approach. New York: Palgrave Macmillian.

Prussia, G., Anderson, J.S., \& Manz, C. 1998. SelfLeadership and Performance: The Mediating Influence of Self-Efficacy. Journal of Organizational Behavior, 19(5): 523-538.

Renkema, M. 2018. Innovating HRM for EmployeeDriven Innovation: A Multilevel Perspective. Doctoral Dissertation, The Netherlands: University of Twente, Enschede.

Ryan, R. M., \& Deci, E. L. 2000. Self-determination theory and the facilitation of intrinsic motivation, social development, and well-being. American Psychologist, 55(1): 68-78.

doi:10.1037/0003-066X.55.1.68

Smith, P., Ulhøi, J., \& Kesting, P. 2012. Mapping key antecedents of employee-driven innovations. International Journal of Human Resources Development and Management, 12(3): 124-236. doi:10.1504/ijhrdm.2012.048629
Spector, P.E. 1986. Perceived control by employees: A meta-analysis of studies concerning autonomy and participation at work. Human Relations, 39(11): 10051016. doi:10.1177/001872678603901104

Stewart, G., Courtright, S., \& Manz, C. 2011. SelfLeadership: A Multilevel Review. Journal of Management, Vol. 37: 185-222.

Voxted, S. 2018. Conditions of implementation of employee-driven innovation. International Journal of Entrepreneurship and Innovation Management, 22(4/5): 471-488.

Wihlman, T., Hoppe, M., Wihlman, U., \& Sandmark, H. 2014. Employee-driven Innovation in Welfare Services. Nordic Journal of Working Life Studies, 4(2): 159-180.

Williams, S. 1997. Personality and Self Leadership. Human Resource Management Review, 7(2): 139-155.

Xin, L. 2016. Management Control and Employee-Driven Innovation. Doctoral Dissertation, Harvard Business School, Retrieved from: http://nrs.harvard.edu/urn3:HUL.InstRepos:32744406

Yun, S., Neck, C., Cox, J., \& Sims, H.P. 2006. The forgotten follower: a contingency model of leadership and follower self leadership. Journal of Managerial Psychology, 21(4): 374-388.

doi:10.1108/02683940610663141

Zhou, J. 1998. Feedback Valence, Feedback Style, Task Autonomy, and Achievement Orientation: Interactive Effects on Creative Performance. Journal of Applied Psychology, 83(2): 261-276.

doi:10.1037/0021-9010.83.2.261

\section{About the Author}

Chukwuemeka K. Echebiri is a research fellow at Inland School of Business and Social Sciences, Inland Norway University of Applied Sciences in Elverum. His doctoral thesis focuses on employeedriven innovation from an employee empowerment perspective. He holds an MSc in Business from Nord University School of Business, Norway. His work experience cuts across banking, insurance, and academics.

Citation: Echebiri, C.K. 2020. An Empirical Study into the IndividualLevel Antecedents to Employee-Driven Innovation. Technology Innovation Management Review, 10(6): 42-52.

http://doi.org/10.22215/timreview/1367

(cc) BY

Keywords: Employee-driven innovation, self-leadership, need for autonomy, job autonomy. 